\title{
The impact of board and audit committee characteristics on voluntary disclosure: a meta-analysis
}

\author{
Khaled Samaha, Hichem Khlif and Khaled Hussainey
}

Forthcoming: Journal of International Accounting Auditing and Taxation

\begin{abstract}
In this paper we apply meta-analysis to a sample of 64 empirical studies to identify the potential moderators to the relationship between board, audit committee characteristics and voluntary disclosure. We examine whether the results are affected by the differences in the construction of disclosure index, the type of voluntary disclosure, the method of disclosure, the definitions of variables relating to corporate governance, the level of investor protection, and country geographic location. We find that, whilst board size, board composition and audit committee have a significant positive effect on voluntary disclosure, CEO duality has a significant negative effect. In addition, country geographic location moderates the association between board size, board composition, CEO duality and voluntary disclosure. Furthermore, the association between CEO duality and voluntary disclosure is moderated by disclosure type, disclosure method and the level of investor protection. Finally, differences in the definitions of explanatory variables moderate the association between board composition and voluntary disclosure. We conduct a sensitivity analysis which provides evidence that, in respect of the time period, prior to 2002, CEO duality has a significant negative effect on voluntary disclosure and has an insignificant effect for the period thereafter.
\end{abstract}

Keywords: Board characteristics, audit committee, type of voluntary disclosure, disclosure index construction, disclosure method, investor protection level, country geographic location, meta-analysis.

\section{Acknowledgements}

The authors are indebted to the two anonymous reviewers and the editors in chief for their helpful and detailed comments on the previous versions of this manuscript. 


\section{The impact of board and audit committee characteristics on voluntary disclosure: a meta-analysis}

\section{Introduction}

Although disclosure theories suggest a positive association between corporate governance and disclosure, empirical research offers mixed results (Wang \& Hussainey, 2013). Brown, Beekes, and Verhoeven (2011:153) note that since the literature on corporate governance "already has a degree of maturity, most improvements will be incremental". Generally, empirical evidence is restricted to only one country and, consequently, this may reduce the capability to ascertain and generalize the research findings which limits the theoretical development of this research area. To gain a better understanding of the association between corporate governance and voluntary disclosure, we conduct a meta-analysis of 64 empirical studies ${ }^{1}$.

Anderson, Mansi and Reeb (2004: 319 \& 320) state that, "In the debate over director efficacy, prior literature primarily focuses on four board characteristics; (i) board independence, (ii) board size, (iii) committee structure, and (iv) specific occupational characteristics or expertise of independent directors". The worldwide codes of best practice recommend that a corporation should have a large and independent board of directors; separate roles for the chairman and CEO; and a large and independent audit committee (Gregory, 2009). Given this importance, we focus on these governance attributes ${ }^{2}$.

For this paper, our motivation is to reconcile the inconsistent research findings and draw logical conclusions which are not obvious from narrative reviews. Narrative reviews suffer

\footnotetext{
${ }^{1} 64$ studies as compared to the 27 studies in García-Meca and Sánchez-Ballesta (2010).

${ }^{2}$ In order to assess meta-analytically the effect of internal governance attributes on voluntary disclosure, it is necessary to have a sufficiently large number of studies which address empirically a particular research question. Our decision to focus on specific mechanisms is influenced by this criterion. Initially, we look for other board characteristics including the number of meetings and the percentage of financial expertise. However, given the limited number of studies, we discard these variables in order to obtain robust meta-analytic findings.
} 
from a lack of acceptable rules to extend the individual results to generalized findings. Therefore, these can lead to false conclusions since, generally, the differences of the significance across studies are attributed to the sampling errors (Rosenthal, 1991).

Our paper offers three novel contributions. First, when compared to Pomeroy and Thornton's (2008) and García-Meca and Sánchez-Ballesta's (2010) studies, we offer distinguishing features. Pomeroy and Thornton (2008) focus on the independence of audit committee whilst García-Meca and Sánchez-Ballesta (2010) examine board independence and ownership concentration. We complement this line of research by considering several corporate governance attributes (board size, board composition, CEO duality and audit committee). Second, by focusing on intellectual, social, environmental and internet disclosures, we are motivated by García-Meca and Sánchez-Ballesta (2010:622) who call for "new analyses, studying for example whether the results depend on the type of voluntary information reported (social, environmental, intellectual capital, etc.)". Finally, we examine whether disclosure index construction, disclosure method, the definition of explanatory variables and research settings ${ }^{2}$ moderate the results reported in the empirical literature.

Our meta-analytic findings show that country geographic location moderates the association between board size, board composition, CEO duality and voluntary disclosure. In addition, we find that the level of investor protection, the type and the method of disclosure affect the relationship between CEO duality and voluntary disclosure. Finally, we document that the proxies used to measure explanatory variables moderate the relationship between board composition and voluntary disclosure.

The remainder of this study is organized as follows. Section 2 reviews the literature and formulates the hypotheses. Section 3 describes the data collection. Section 4 presents the methodology. Section 5 reports the results. Section 6 concludes.

\footnotetext{
${ }^{2}$ We use an updated classification of countries and investor protection ranking.
} 


\section{Literature Review}

Board and audit committee characteristics are considered as key determinants of corporate reporting policy (Chau \& Gray, 2010; Chen \& Jaggi, 2000). In this section, we review the theoretical foundations for the association between board size, board composition, CEO duality, audit committee and voluntary disclosure.

\subsection{Board Size}

Board size may play an important role in promoting corporate transparency. For instance, a large board size may be beneficial to the firm since it increases the pool of expertise and available resources (Hidalgo, García-Meca, \& Martínez 2011). Based on the concept of expert power, a large board size allows diverse experiences and opinions which, in turn, increase the board's supervisory capacity implying more voluntary disclosure (Gandia, 2008).

On the other hand, Herman (1981) argues that large boards are more likely to be ineffective. For instance, Lipton and Lorsh (1992) suggest that the arrangement of meetings and the reaching of a consensus, concerning some issues discussed during the board meetings, are more difficult for a company characterized by a large board. Therefore, the board's monitoring ability is reduced implying less effectiveness and, consequently, less voluntary information.

Empirical studies are supportive of a positive association between board size and voluntary disclosure (e.g. Abeysekera, 2010; Allegrini \& Greco, 2013). However, other empirical works, including Arcay and Vazquez (2005) and Prado-Lorenzo and Garcia-Sanchez (2010) find that there is an insignificant association between both variables. Therefore, we formulate the following non-directional hypothesis:

H1: There is an association between board size and voluntary disclosure.

\subsection{Board Composition}


Agency theory suggests that the existence of independent directors on the board may have a significant impact on the effectiveness of board's monitoring activities (Fama \& Jensen, 1983). Based on the reputation effect, Patelli and Principe (2007) argue that, by providing more voluntary disclosure, outside directors may gain greater public esteem to build their reputations as expert monitors in the labor market. García-Meca and Sánchez-Ballesta (2010) use the 'domino effect' concept of independent directors to push inside board members to improve corporate reporting policy through more voluntary disclosure.

By contrast, Patelli and Principe (2007) suggest that outside directors are normally appointed by dominant shareholders. In case of collusion with them, the monitoring role of independent directors will be limited (Demb \& Neubauer, 1992). Under these conditions, the presence of a high proportion of outside directors may have a negative effect on voluntary disclosure.

The empirical evidence on the association between board composition and voluntary disclosure is inconclusive. While Adams and Hossain (1998) and Cheng and Courtenay (2006) find a significant positive association between voluntary disclosure and board composition, Abdelsalam and Street (2007) and Eng and Mak (2003) document a negative association between both variables. Therefore, we formulate the following non-directional hypothesis:

H2: There is an association between board composition and voluntary disclosure.

\subsection{CEO Duality}

A combined leadership structure may facilitate CEO entrenchment (Pfeffer, 1981) and it is considered as the primary cause of the misalignment of interests (Kim, Al-Shammari, Kim, \& Lee, 2008). On the one hand, Fama and Jensen's agency framework (1983) indicates that a unified leadership structure reduces the importance of the separation between decision control (chair of the board) and decision management (CEO). Accordingly, CEO duality may constrain the desired system of checks and balances and compromise the board independence 
in overseeing top management behavior (Cerbioni \& Parbonetti, 2007). On the other hand, the CEO has a superior knowledge of the private information dealing with the firm's competitive advantages and its internal conditions. Therefore, duality may limit the complete transfer of private information between the $\mathrm{CEO}$ and board members resulting in less voluntary disclosure (Kim et al., 2008).

However, Anderson and Anthony (1986) point out that duality enables a clear-cut leadership in the formulation and the implementation of firm's strategy and this leads to greater efficiency. They argue that a unified leadership structure reduces information sharing costs and conflict of interests between CEO and non-CEO chairman. Proponents of duality also highlight the importance of clear lines of authority and unity of commend to reduce conflicts and improve decision making (Rhoades, Rechner \& Sundaramuthy, 2001). Therefore, CEO duality may result in more voluntary disclosure.

We also note that the empirical evidence on the relationship between voluntary disclosure and CEO duality is mixed. Whilst Allegrini and Greco (2013) and Li et al. (2008) document a significantly negative association between CEO duality and voluntary disclosure, other studies (e.g. Cheng \& Courtenay, 2006; Haniffa \& Cooke, 2002) report an insignificant or a positive association between both variables. Therefore, we formulate the following nondirectional hypothesis:

H3: There is an association between CEO duality and voluntary disclosure.

\subsection{Audit Committee}

The key role of audit committee is to assist the board of directors in overseeing corporate reporting policy (Pincus, Rusbarsky, \& Wong, 1989). For instance, Arcay and Vazquez (2005) suggest that, in terms of clarity, relevance and completeness of information an audit committee plays a crucial role in fulfilling investors' needs for information. As a control mechanism over top management, an audit committee ensures that there is an increased 
voluntary disclosure to allow an accurate assessment of the top management's decisions and behaviors (Allegrini \& Greco, 2013) and align the management's and the shareholders' interests (Laksmana, 2008). Therefore, such a monitoring mechanism is expected to improve corporate reporting policy. For instance, The Blue Ribbon Report (1999) and the Smith Report (2003) suggest that the audit committee plays a pivotal role in monitoring board activities by improving the quality of the disclosed information and ensuring the protection of shareholders' interests through the release of price-sensitive information.

Generally, we note that empirical studies are supportive of a positive association between audit committee characteristics and voluntary disclosure (Al-Shammari \& Al-Sultan, 2010; Barako et al. 2006 and Ho \& Wong, 2001). By contrast, some studies do not find such an association (e.g. Allegrini \& Greco, 2013 and Mangena \& Pike, 2005). Therefore, we formulate the following non-directional hypothesis:

H4: There is an association between audit committee characteristics and voluntary disclosure.

\subsection{Variables intervening in the association between board, audit committee characteristics and voluntary disclosure}

By considering the potential moderators to the relationship between governance attributes and voluntary disclosure, we move beyond a simple statistical summary of the association between them. Six potential moderators are successively discussed below.

First, we identify three types of voluntary disclosure scores; total, social, environmental and intellectual capital disclosures. Total disclosure includes different types of information such as historical, financial, social, environmental and intellectual capital information. Total voluntary disclosure is oriented specifically towards stock markets participants and improves investors' abilities to predict future earnings (Gelb \& Zarowin, 2002). The main part of total disclosure score deals with historical financial information (Lim, Matollcky, \& Chow, 2007). Intellectual capital information targets, also, investors' needs since it deals with the firm's future prospects and provides both strategic and competitive advantage information (Meek, 
Roberts, \& Gray, 1995). By contrast, social and environmental disclosure is dominated by information concerning firms' social and environmental actions. Therefore, this kind of information is reserved specifically to satisfy stakeholders' needs and signal firm's legitimacy in its society (Lim et al., 2007).

Since these three types of disclosure integrate different aspects of information and target diverse users of information, different factors are expected to influence each type of information (Lim et al, 2007). This is particularly true for the board of directors which is, generally, aligned with shareholders and focuses on the maximization of profits rather than serving stakeholders' interests (Adams, Licht, \& Sagiv, 2011). Wang and Dewhirst (1992) argue that board characteristics (e.g. CEO duality and the percentage of outside directors) may have an impact on the board's stakeholder orientation and, consequently, on social and environmental disclosure. Lim et al. (2007) find that board characteristics have different effects on disclosure types.

Given the fact that, generally, audit committee and board members are considered as representative of shareholders' interests (Ayuso \& Argandona, 2007), they are more likely to be in line with investors' needs and put more emphasis on financial and strategic information. By contrast, the CEO, who is, also, the chair of the board, will try to reduce financial disclosure to preserve his/her dominant position on the board and facilitate his/her entrenchment. In addition, the proprietary costs theory predicts that CEO will try, also, to reduce the extent of social and environmental disclosure in order to improve the firm's performance in the short term and increase his/her own compensation. Therefore, we formulate the following hypothesis:

H5: Disclosure types intervene in the relationship between board, audit committee characteristics and voluntary disclosure.

Second, we note that the disclosure method (annual report versus company website) may moderate the relationship between voluntary disclosure and the examined governance 
attributes. The annual report is a statutory document that management produces on an annual basis. According to Marston and Shrives (1991) and Beretta and Bozzolan (2004) annual reports represent the "main disclosure vehicle," and the most comprehensive financial report available to the public. The structure of annual report is formalized. Therefore, one can compare the content of these reports between companies. By contrast, web-based disclosure is optional, freely accessed by all types of investors and requires supplementary costs of preparing and updating the firm's website. Consequently, there is an expectation that the board of directors and audit committee members will put more emphasis on the formal communication channel (i.e. annual report disclosure). Therefore, we formulate the following hypothesis:

H6: Disclosure method (annual report versus company website) intervenes in the relationship between board, audit committee characteristics and voluntary disclosure.

Third, we also note that the conflicting findings across studies can be attributed to the diversity of the respective countries' legal and institutional systems. For instance, the level of investor protection may affect the relationship between board of directors, audit committee characteristics and voluntary disclosure (La Porta, Lopez-de-Silanes, Shleifer, \& Vishny, 1998). We note that, in an environment characterized by a high level of investor protection, directors face more litigation risk. Consequently, they are inclined to improve corporate reporting policy in order to reduce the information asymmetry between large and minority shareholders. By contrast, a CEO, who is, also, the chair of the board, will try to reduce the extent of voluntary disclosure in order to diminish, in a high investor protection setting, litigation risk. Therefore, we formulate the following hypothesis:

H7: The level of investor protection intervenes in the relationship between board, audit committee characteristics and voluntary disclosure.

Fourth, legal origin and institutional characteristics play an important role in shaping corporate governance mechanisms and their effects on voluntary disclosure (García-Meca \& Sánchez-Ballesta, 2010). For instance, Ahmed and Courtis (1999: 36) suggest that 'these 
inconclusive results could be due to differences in socio economic and political environments between countries'.

The Report on Observance of Standards and Codes (e.g. Egypt, 2009) suggests that, whilst many directors may be outside the firm, they may not be truly independent since, generally, they have close relationships with large owners. Similarly, in Kenya, Barako et al. (2006) suggest that outside directors are not truly independent since they have close relationships with large shareholders. This situation may compromise the board's and the audit committee's roles in enhancing corporate reporting policy. When directors are not truly independent, the CEO will operate in a more comfortable situation which, in turn, increases his/her discretion over corporate reporting policy. Therefore, we formulate the following hypothesis:

H8: Country geographic location intervenes in the relationship between board, audit committee characteristics and voluntary disclosure.

Fifth, we note that there is no definitive theoretical guidance concerning how to construct a disclosure index and, consequently, researchers develop the index often based on their objectives (Artiach \& Clarkson, 2011). Whilst some researchers use a dummy variable approach to measure voluntary disclosure, others estimate the extent of voluntary disclosure using a disclosure checklist. According to Bravo, Abad, and Trombetta (2010), the second approach is more able to capture the richness of firm's voluntary disclosure policy. Accordingly, we place studies into two groups to assess the moderating effect of the disclosure index construction on the association between voluntary disclosure and the examined governance attributes. Therefore, we formulate the following hypothesis:

H9: The construction of the disclosure index intervenes in the relationship between board, audit committee characteristics and voluntary disclosure.

Finally, we note that prior meta-analyses on the determinants of voluntary disclosure (GarcíaMeca \& Sánchez-Ballesta, 2010; Khlif \& Souissi, 2010), argue that, the differences in the 
definition of explanatory variables, can affect the hypothesized relationships ${ }^{3}$. The empirical literature uses three main proxies to measure board composition, namely, board independence (e.g. Patelli \& Prencipe, 2007), non-executive directors (e.g. Haniffa \& Cooke, 2002), and independent non-executive directors (e.g. Ghazali \& Weetman, 2006). Corporate governance literature (e.g., Dalton et al., 1999) suggests that, in substance, executive directors are not so independent. Therefore, we expect that this proxy for board composition is less linked to voluntary disclosure. Similarly, we note that audit committee characteristics are measured using different proxies including the existence of an audit committee, the percentage of independent members and the size of audit committee. This diversity of measures may also moderate the relationship between audit committee and voluntary disclosure. Therefore, we formulate the following hypothesis:

H10: The proxies, used to measure board size, board composition and audit committee characteristics, intervene in the relationship between these governance attributes and voluntary disclosure.

\section{Sample of studies included in the meta-analysis}

We conduct an extensive search for relevant articles. We collect papers from several accounting and finance journals indexed by Science Direct, EJSEbsco, Blackwell, Springer, Emerald, Inderscience, ABI Inform, and Social Science Research Network (SSRN). Our initial search uses keywords including: "voluntary disclosure and corporate governance mechanisms". The term voluntary is then replaced by "internet-based, intellectual capital and social and environmental". In order to identify the maximum number of empirical studies dealing with such a topic, we replace the word "corporate governance" with "board characteristics", "CEO duality" and "audit committee". We also consult specialized journals of accounting and finance (e.g. Corporate Governance: An International Review, Journal of Management Governance) and references in the collected studies. Initially, we search for

\footnotetext{
${ }^{3}$ With the exception of some studies that use a dummy variable that takes 1 , if directors on the board exceed a certain number and, 0 otherwise, board size is measured commonly by the number of directors.
} 
several board characteristics including board size, board composition, CEO duality, the number of audit committee meetings, the percentage of financial expertise, and audit committee characteristics. However, we focus only on board size, board composition, CEO duality and audit committee characteristics and we discard the other board characteristics given the limited number of studies allowing us to obtain robust meta-analytic findings.

Our searches yield a total of 64 research articles between 1997 and 2013. Amongst the 64 papers, 34 articles are published in top ranked journals (Elsevier, Wiley-Blackwell, Springer, Francis \& Taylor); 14 in decent journals (Emerald, Inderscience and Macmillan); 15 papers appear in other journals; and only Fleo's (2010) paper is available in SSRN. Therefore, 53 per cent $(34 / 64)$ of the studies examined are published in ranked journals implying more reliability of the statistical inferences in our meta-analysis. Table 1 illustrates the sample selection process and Table 2 presents the studies included in the analysis.

\section{Insert Table 1 about here \\ Insert Table 2 about here}

\section{Meta-analysis technique}

Meta-analysis is an alternative to a narrative literature review. It is defined as a statistical method to summarize and analyze previous quantitative empirical literature. Narrative review may be misleading since individual studies may have different characteristics in term of sample size, variables proxies and time period (Hunter \& Schmidt, 1990). The meta-analysis technique allows researchers to examine the effect of these different data characteristics on the findings of primary studies (Hunter \& Schmidt, 1990; Rosenthal, 1991).

\subsection{Effect size}

In meta-analysis, the effect size measures the magnitude of the relationship between two variables. In our study, it represents a metric proxy of the degree of connection between 
voluntary disclosure and explanatory variables ${ }^{4}$. Meta-analytic data should be analyzed using the following three steps as suggested by Hunter et al. (1982) and Hunter and Schmidt (2000).

(i) Firstly, the mean correlation $(\bar{r})$ is calculated as: $\bar{r}=\frac{\sum\left(r_{i} \cdot N_{i}\right)}{\sum N_{i}} \quad\left(1\right.$; where $N_{\mathrm{i}}$ is the sample size and $r_{i}$, is the Pearson correlation coefficient for study $i$.

(ii) Secondly, the observed variance $\left(S_{r}^{2}\right)$ and the sampling error variance $\left(S_{e}^{2}\right)$ are calculated using the following formulas $S_{r}^{2}=\frac{\sum N_{i}\left(r_{i}-\bar{r}\right)^{2}}{\sum N_{i}}$ (2) and $S_{e}^{2}=\frac{\left(1-\bar{r}^{2}\right)^{2} K}{\sum N_{i}}$ (3) where $K$ is the number of individual studies included in the meta-analysis.

(iii) Finally, the estimates of population mean $(\bar{r})$ and the standard deviation $\sqrt{S_{r}^{2} / K}$ are used normally to construct a 95 per cent confidence interval.

In order to test for moderating variables and determine whether the observed variance is trivial or higher than expected, a chi-square statistic $\left(\chi_{K-1}^{2}=\frac{N S_{r}^{2}}{\left(1-\bar{r}^{2}\right)^{2}}(4)\right)$ is used to assess whether the observed variance is due to moderating effects or to some statistical errors. If the computed chi-square statistic is inferior to the tabulated one, the association is considered to be homogeneous and the variation in results across studies is due only to some statistical errors. Nevertheless, if the computed chi-square statistic is significant at the 5 per cent significance level, we conduct further analyses to test for moderators and reduce the heterogeneity in the observed variance.

\subsection{Moderating factors}

We consider six moderating variables. Disclosure score is classified into: total score (TS); intellectual capital disclosure (ICD); and social and environmental disclosure (CSED). As the second moderating factor, we consider annual reports disclosure against internet-based

\footnotetext{
${ }^{4}$ In computing the effect size from the reported statistics, different procedures can be used. When a study reports Pearson's $r$ coefficient, such a statistic is used to calculate the effect size between voluntary disclosure score and explanatory variable. When other statistics such as Student $t$ and $Z$ value are reported, the following formulas are used to compute the effect size respectively $\sqrt{\frac{t^{2}}{\left(t^{2}+d f\right)}}$ where $d f$ is the degree of freedom and $\frac{Z}{\sqrt{N}}$.
} 
disclosure. In the third and fourth moderating factors, we examine the moderating effect of country geographic location ${ }^{5}$ and the level of investor protection ${ }^{6}$. As the fifth moderating factor, we consider the approach used to measure voluntary disclosure (disclosure checklist versus a dummy variable: 1 if the information is disclosed and 0 otherwise). Finally, board size is sub-grouped into: the number of directors on the board; and a dummy variable. Board composition is sub-grouped into: the percentage of independent directors (PID); the percentage of independent non-executive directors (PIND); and the percentage of nonexecutive directors (PND). Audit committee is sub-grouped into: dummy variable (DV): 1 if audit committee exists and 0 otherwise; the number of audit committee members (NAC) and the percentage of independent non-executive directors (INDC).

\section{Results}

Tables 3 and 4 summarize the study's results. In each table, we present, firstly, the results of the overall meta-analysis and, if the homogeneity test is rejected, we conduct refined analyses according to the moderating factors cited above.

\subsection{Board size}

The board size has a mean correlation of $0.193(\mathrm{Z}=8.137)$ with a 95 per cent confidence interval between 0.146 and 0.239 (Table 3 A). Therefore, the results support hypothesis $\mathrm{H}_{1}$. However, only 41.659 per cent of the observed variance is explained by the sampling error variance. This indicates a high degree of heterogeneity across studies. This is also evident

\footnotetext{
${ }^{5}$ We group together countries which share several similarities in terms of disclosure policy; directors' liability; and the ease of shareholders suits. Based on the World Bank's classification, we identify the following five groups : (i) MENA including Egypt, Iran, Saudi Arabia, Tunisia and Turkey; (ii) OECD high income countries including Australia, Canada, France, Greece, Italy, Ireland, New Zealand, Spain, UK and USA; (iii) Sub-Saharan Africa (SA) including Kenya, Nigeria and Zimbabwe; and (iv) East Asia Pacific (EAP) including Bangladesh, China, Hong Kong, Indonesia, Malaysia and Singapore. ${ }^{6}$ We classify studies with respect to the level of investor protection in the countries examined. High (low) investor protection countries are those which have an investor protection ranking inferior (superior) to the median of our sample.
} 
from the significant $(p<0.01)^{7}$ chi-square statistic of 64.810. In order to reduce heterogeneity ${ }^{8}$, we undertake further tests for moderating variables.

When we conduct a sub-group meta-analysis with respect to disclosure type (social and environmental, intellectual and total score disclosures), there remains a significant association regardless the type of disclosure. Similarly, disclosure method (annual report versus webbased) does not moderate the examined relationship. Therefore, we establish that $\mathrm{H}_{5}$ and $\mathrm{H}_{6}$ are not supported. In addition, when the checklist approach is used to measure disclosure score, the relationship is also significant with a mean correlation of $0.192(Z=8.152){ }^{9}$

When we examine the moderating effect of the level of investor protection, the results show that the association remains significant for high and low investor protection groups $(0.224 ; \mathrm{Z}$ $=10.246)$ and $(0.183 ; \mathrm{Z}=3.878)$ respectively. Therefore, $\mathrm{H} 7$ is rejected. With respect to geographic location, the association remains significant for OECD high income countries (0.252; $Z=6.224)$, East Asia and Pacific settings $(0.210 ; Z=8.617)$ and Sub-Saharan African countries $(0.226 ; Z=3.321)$. By contrast, the relationship becomes insignificant for MENA region $(0.068 ; \mathrm{Z}=0.753)$. Therefore, $\mathrm{H}_{8}$ is supported. However, this result should be interpreted with cautions given the insufficient number of studies for some regions (e.g. MENA and Sub-Saharan African settings).

Finally, the meta-analytic results show that there is only a significant association between board size and voluntary disclosure when the former is proxied by the number of directors on the board with a mean correlation $0.200(\mathrm{Z}=8.403)$, whilst, as measured by a dummy variable $(-0.001 ; Z=-0.026)$, there is an insignificant association. Therefore, $\mathrm{H}_{10}$ is supported.

\footnotetext{
${ }^{7}$ The tabulated chi-square, with a degree of freedom of $(27-1=26)$ at significance level of 0.01, accounts for 45.642.

${ }^{8}$ Corporate governance literature (e.g. Boone, Field, Krapoff and Raheja, 2007) suggests other moderating factors including firm size, firm's degree of diversification and tension between monitoring and strategy roles. However, the primary data, which we collect from empirical studies, does not allow us to control these moderating factors in respect of the relationship between board size and voluntary disclosure.

${ }^{9}$ Since only the paper of Buniamin et al. (2008) uses a dummy variable approach, we can not test for H9.
} 
However, given the limited number of studies for dummy variable group, this result should be interpreted with cautions.

\subsection{Board composition}

As shown in Table 3 (B), the relationship between voluntary disclosure and board composition has a mean correlation of $0.115(Z=6.096)$ and a 95 per cent confidence interval between 0.078 and 0.152 . Since the overall explanatory power of this variable is substantially low $\left(\chi_{K-1}^{2}=194.498 ; p<0.001\right)$, we undertake further analyses to test for the presence of moderating variables.

When we sub-group studies according to disclosure scores, there is, also, a significant association for total, social, environmental and intellectual capital scores. Therefore, these results do not confirm $\mathrm{H}_{5}$. When we classify studies according to disclosure method (annual report versus web), the findings show that there remains a significant association for webbased disclosure $(0.108 ; Z=2.469)$, and annual report disclosure $(0.116 ; Z=5.596)$. Therefore, $\mathrm{H}_{6}$ is rejected. Furthermore, when we conduct a sub-group meta-analysis with respect to disclosure index construction, the findings show a significant mean correlation of $0.125(\mathrm{Z}=6.076)$ for the checklist index group. By contrast, the relationship becomes insignificant for the dummy variable index group with a mean correlation of $0.046(\mathrm{Z}=$ 1.100). Therefore, the construction of disclosure index moderates the relationship and $\mathrm{H} 9$ is supported. This result should be interpreted with cautions given the limited number of studies using a dummy variable approach.

Another moderating variable, the definition of board composition, shows that the studies, employing the percentage of independent directors and independent non-executive directors, have significantly positive mean correlations of $0.137(\mathrm{Z}=7.056)$ and $0.167(\mathrm{Z}=3.870)$ respectively. On the other hand, the association becomes insignificant for studies employing 
the percentage of non-executive directors $(0.047 ; \mathrm{Z}=1.018)^{10}$. Our results are in line with García-Meca and Sánchez-Ballesta (2010) who, also, find that there is an insignificant association between the percentage of non-executive directors and voluntary disclosure. Therefore, the proxies used to measure board composition moderate the relationship. These findings support $\mathrm{H}_{10}$.

When we classify studies according to the level of investor protection, the results remain significant for high and low investor protection groups $(0.117 ; \mathrm{Z}=5.247)$ and $(0.112 ; \mathrm{Z}=$ 3.561) respectively. Hence, $\mathrm{H}_{7}$ is not supported.

With respect to geographic location, there is a significant association for OECD high income countries $(0.134 ; Z=5.283)$ and East Asia Pacific countries $(0.125 ; Z=4.799)$. By contrast, there is an insignificant association for MENA settings $(0.059 ; \mathrm{Z}=1.161)$ and Sub-Saharan African countries $(-0.102 ; Z=-0.974)$. Consequently, country geographic location moderates the relationship and this supports hypothesis $\mathrm{H} 8$.

\section{Insert Table 3 about here}

\subsection{CEO duality}

Table $4(\mathrm{C})$ shows that there is a significant negative relationship between CEO duality and voluntary disclosure with a mean correlation of $-0.053(Z=-2.796)$ and a confidence interval between -0.091 and -0.016 . We reject the homogeneity test since 33 per cent of the observed variance is explained by the sampling error variance. This is also evident from the significant $(p<0.01)$ chi-square statistic of 97.581 . Therefore, we conduct further analysis to test for the presence of moderating variables.

When we classify studies according to disclosure score, there remains a significant negative association for social and environmental score $-0.064(Z=-3.441)$ and total score $(-0.070 ; Z=$ -1.950), while it is insignificant for intellectual capital information $(-0.001 ; Z=-0.020)$.

\footnotetext{
${ }^{10}$ We exclude the study of Abeysekera (2010) from the analysis since it uses the number of independent directors on the board.
} 
Therefore, these results support hypothesis H5. As predicted by the proprietary costs theory, the dissemination of social and environmental information increases disclosure costs. CEO will try to avoid such a type of voluntary disclosure to improve the firm's short term profitability and, thus, his/her own compensation. When we examine the moderating effect of disclosure method, we document that the negative association is maintained for annual report disclosure $(-0.061 ; Z=-2.748)$, whilst it is insignificant for internet-based disclosure $(-0.006$; $\mathrm{Z}=-0.023)$. Therefore, these results also support hypothesis $\mathrm{H} 6$.

Moreover, since there is a significant association for the disclosure checklist method (-0.053; $Z=-2.551)$ and the dummy variable approach $(-0.062 ; Z=-5.428)$, we conclude that the disclosure construction approach does not moderate the association.

When we examine the moderating effect of the level of investor protection, we find that there is a significantly negative relationship for high investor protection group $(-0.081 ; \mathrm{Z}=$ -3.892), whilst it becomes insignificant for low investor protection group $(-0.024 ; \mathrm{Z}=$ -0.762). Therefore, these results support hypothesis $\mathrm{H} 7$. Our findings are consistent with those reported by Rogers and Van Buskirk (2009), which suggest that, despite the high quality judicial systems, the litigation process reduces managers' incentives to disclose information. Similarly, we find that the country geographic location moderates the relationship between CEO duality and voluntary disclosure since there is only a significant negative association for OECD high income countries with a mean correlation of $-0.072(Z=-2.167)$ and a confidence interval between -0.138 and -0.007 . Therefore, these results also confirm hypothesis $\mathrm{H}$.

\subsection{Audit committee}

Table 4 (D) reports the results of 22 studies in respect of the relationship between audit committee and voluntary disclosure. The overall meta-analysis results show a significant association between both variables with a mean correlation of $0.199(\mathrm{Z}=6.498)$ and a 95 per cent confidence interval between 0.139 and 0.260 . Therefore, $\mathrm{H}_{4}$ is accepted. The computed 
chi-square statistic of $103.002(p<0.05)$ and the percentage of observed variance explained by the sampling error variance of 21.358 indicate a high degree of heterogeneity across studies. Therefore, we undertake further analyses to identify moderators.

When we study the moderating effects related to voluntary disclosure, the relationship remains significant regardless the type of disclosure score, the approach used to construct disclosure index and the disclosure method. Therefore, these results do not support hypotheses $\mathrm{H}_{5}, \mathrm{H}_{6}$ and $\mathrm{H}_{9}$. The lack of moderation for disclosure type and tool should be interpreted with cautions given the limited number of studies for some disclosure types (social, environmental and intellectual capital information) and internet-based disclosure.

When we sub-group studies according to the proxies used to measure the audit committee variable (the percentage of independent directors, the number of audit committee members and a dummy variable), the association remains significant with mean correlations of 0.105 ( $\mathrm{Z}$ $=4.039), 0.171(Z=3.195)$ and $0.293(Z=6.322)$ respectively. Therefore, the proxy used to measure the audit committee variable does not moderate the relationship and $\mathrm{H}_{10}$ is rejected.

Finally, we undertake further meta-analytic comparisons by grouping studies according to the level of investor protection and country geographic location. The meta-analytic findings show that, for all the groups, the significant relationships remain. Therefore, the level of investor protection and country geographic location do not moderate the examined relationship and, thus, $\mathrm{H}_{7}$ and $\mathrm{H}_{8}$ are rejected. Here it should be noted that, given the limited number of studies, the results, obtained for Sub-Saharan African and MENA countries, have to be interpreted with cautions.

\section{Insert Table 4 about here}

A summary of meta-analytic results is shown in Table 5.

Insert Table 5 about here 


\subsection{Additional and sensitivity analysis ${ }^{11}$}

Before 2002, numerous financial scandals have accrued (e.g. Enron in the USA). Since metaanalysis allows researchers to examine how time period affects the primary studies' findings (Hunter \& Schmidt, 1990), we control for time effect by considering the period before 2002 (including 2002) and the period thereafter. We exclude all studies using samples spanning from the pre- to the post-2002 periods. The results show that, for the pre- and post-2002 periods, there remains a significant association between board size, board composition, audit committee and voluntary disclosure. However, for the pre-2002 period, there is a significant negative relationship for CEO duality $(-0.096 ; Z=-3.238)$, while there is an insignificant relationship $(-0.039 ; Z=-1.671)$ for the post-2002 period. We also conduct tests of equality of means for pre- and post-2002 periods. Results show that there is an insignificant change for the association between board size and voluntary disclosure with a T-statistic of 0.216 . For board composition, the mean correlation witnesses a significant increase moving from 0.105 for the pre-2002 period to 0.124 for the post-2002 period with a T-statistic of 6.998. For CEO duality, the mean correlation moves from -0.096 for the pre-2002 period to -0.039 for the post-2002 period with a significant T-statistic of 22.110. Finally, the mean correlation for audit committee witnesses a significant decrease moving from 0.284 for pre-2002 period to 0.184 for the post-2002 period with a T-statistic of -16.650 .

In order to test whether the publication bias influences the conclusions drawn from our metaanalysis, we apply Orwin's (1983) approach to determine the extent of the file drawer problem. This method requires the estimation of the fail-safe $N$ being the number of unreported studies with insignificant results required to reduce the mean effect size to a

\footnotetext{
${ }^{11}$ Although several authors call for the control of endogeneity when examining the association between disclosure and corporate governance attributes (e.g. Core, 2001; Hermalin, and Weisbach, 2003) as for corporate governance and corporate performance, the majority of studies dealing with this stream of research consider corporate governance attributes as a determinant of disclosure policy. Therefore, it is not possible for us to control for reverse causality or endogeneity since primary studies in their models consider voluntary disclosure as a consequence of board and audit committee characteristics.
} 


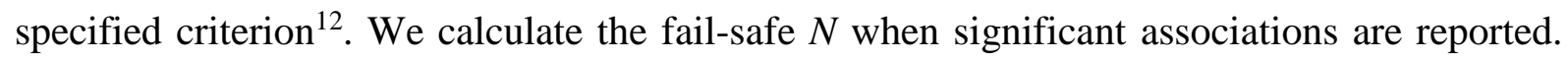
The file drawer analysis indicates the stability of significant results obtained for the overall samples since the fail-safe $N$ ranges from 33 for board size to 14 for CEO duality. When subsamples include a limited number of studies, the computed fail-safe $N s$ also indicate the stability of the results for audit committee variable (MENA and Sub-Saharan African settings) and board size (Sub-Saharan African settings).

We conduct another sensitivity analysis with respect to the type of items included in the total scores. We identify 14 studies $^{13}$ which focus exclusively on financial information in their disclosure index. For board size and audit committee, there remains a significant association for financial information and mixed information scores. By contrast, for board composition, the significantly positive association is maintained only for financial scores $(0.132 ; \mathrm{Z}=$ 3.581), whilst it is insignificant for mixed information scores $(0.074 ; \mathrm{Z}=1.907)$ with a confidence interval between -0.002 and 0.150 . Similarly, there is a significant negative association between total score and CEO duality only for financial scores $(-0.097 ; \mathrm{Z}=$ -3.110), whilst it is insignificant for the mixed information scores $(-0.050 ; Z=-0.810)$. This sensitivity test also supports hypothesis H5 since disclosure type moderates the association between board composition, CEO duality and voluntary disclosure.

Moller and Jennions (2001) suggest that the meta-analytic results may be affected by the publication bias since quality journals tend to accept studies with significant results. Therefore, we divide our overall sample into two groups: (i) quality journals and (ii) low quality journals. The results show that the publication quality does not moderate the relationship between board size, board composition, audit committee and voluntary

\footnotetext{
${ }^{12}$ We calculate the fail-safe $\mathrm{N}$ using the following equation: $K_{0}=K\left[\frac{E S_{k}}{E S_{0}}-1\right]$; Ko: the fail-safe $\mathrm{N}$ or the number of insignificant, unpublished studies; K: the number of studies included in the meta-analysis; $E S_{\mathrm{k}}$ : the effect size of studies included in the analysis and $E S_{0}$ :the criterion effect size level which would reduce the effect size.

${ }^{13}$ The studies which deal exclusively with financial information are as follows: (Adams \& Hossain, 1998; Allegrini \& Greco, 2013; Apostolou \& Nanopoulos, 2009; Arcay \& Vazquez, 2005; Baek et al., 2009; Bujaki \& McConomy, 2002; Cheng \& Courtenay, 2006; Chen \& Jaggi, 2000; Juini, 2013; Fleo, 2010; Khodadadi et al., 2010; Mangena \& Pike, 2005; Mangena \& Tauringana, 2007 and Mohamad \& Sulong, 2010).
} 
disclosure. By contrast, the publication quality moderates the association between CEO duality and voluntary disclosure since the mean correlation accounts for $-0.064(Z=-2.447)$ for high quality papers, whilst it amounts to $-0.044(Z=-1.599)$ for low quality journals.

The analyses, presented above, include all the effects from all the studies which may cause a stochastic dependence amongst the observations. In order to address this concern, we use only one observation per study as a sensitivity analysis. The sensitivity meta-analytic findings show that there remains a significant association with a high degree of homogeneity for board size, board composition and audit committee. The mean correlations and chi-square statistics account for $\left(0.207(\mathrm{Z}=7.561) ; \chi_{K-1}^{2}=0.600\right) ;\left(0.143(\mathrm{Z}=6.437) ; \chi_{K-1}^{2}=1.323\right)$; and $(0.237(\mathrm{Z}$ $\left.=6.824) ; \chi_{K-1}^{2}=0.655\right)$ respectively. By contrast, there is an insignificant association for CEO duality since the mean correlation and chi-square statistic account for $(-0.035(Z=-1.439)$; $\left.\chi_{K-1}^{2}=0.668\right)$.

Finally, we control for outliers in our meta-analysis ${ }^{14}{ }^{15}$. For board size, we identify 5 studies as outliers. After dropping them from the analysis, the mean correlation becomes $0.202(\mathrm{Z}=$ 8.623) with an insignificant $\chi_{K-1}^{2}$ of 23.929. Similarly, we identify 9 outliers for the association between board composition and voluntary disclosure. Following their elimination, the association becomes more significant $\left(0.125(\mathrm{Z}=8.397) ; \chi_{K-1}^{2}=123.874\right)$. After dropping 3 studies identified as outliers, there is, also, a more significant relationship for CEO duality

\footnotetext{
${ }^{14}$ We identify outliers by using the Huffcutt and Arthur's (1995) sample-adjusted meta-analytic deviancy statistic (SAMD). For each study, we compute the SAMD as follows: $S A M D(i)=\frac{r_{i}-\bar{r}}{\sqrt{\operatorname{Var}(i)-\operatorname{Var}(\bar{r})}}$ Where: $\operatorname{Var}(i)=\frac{\left(1-\bar{r}^{2}\right)^{2}}{N_{i}-1}$ and $\operatorname{Var}(\bar{r})=\frac{\left(1-\bar{r}^{2}\right)^{2}}{N-K}$; then we compute $\overline{S A M D}$ and $\operatorname{Var}(S A M D)$ to obtain a standardized absolute value of SAMD as follows: $\left|\frac{S A M D-\overline{S M A D}}{\sqrt{\operatorname{Var}(\operatorname{SAMD})}}\right|$. The effect size of the study is not considered to be an outlier if it is close to 0 (Huffcutt and Arthur, 1995). In our analysis, we consider a cut-off point of 1.5. Each study that has a standardized absolute value of SAMD that equals or exceeds 1.5 is considered as outlier and we eliminate it.

15 The studies identified as outliers are as follows: (i) board size (Arcay \& Vazquez, 2005; Allegrini \& Greco, 2013; Gandia, 2008; Prado-Lorenzo \& Garcia-Sanchez, 2010; Samaha et al. 2012); (ii) Board composition (Abdelsalam \& Street, 2007; Adams \& Hossain, 1998; Barako et al., 2006; Eng \& Mak, 2003; Haniffa \& Cooke, 2005; Khan et al, 2013; Mallin et al. 2013; Mangena \& Pike, 2005; Samaha \& Dahawy, 2011); (iii) CEO duality (Rouf, 2011; Al-Janadi et al. 2013; Chau \& Gray, 2010) and (iv) audit committee (Barros et al., 2013; Li et al., 2008; Mangena \& Pike, 2005 Samaha \& Dahawy, 2011).
} 
$\left(-0.058(Z=-4.341) ; \chi_{K-1}^{2}=40.863\right)$. Finally, after dropping 4 studies considered to be outliers, the association between audit committee and voluntary disclosure becomes more significant $\left(0.226(\mathrm{Z}=9.884) ; \chi_{K-1}^{2}=34.384\right)$. The exclusion of outliers leads to more homogeneous relationships since the percentage of the observed variance explained by the sampling error variance amounts to 100 per cent for board size, board composition and CEO duality, while it is about 75 per cent for audit committee. Here, it should be noted that the results generated from sub-group meta-analyses remain stable after the exclusion of outliers.

\section{Conclusion}

In this meta-analysis, we investigate the link between board size, board composition, CEO duality, audit committee and voluntary disclosure. We also test whether the relationships are moderated by the differences in disclosure type, method and construction; the differences in research setting; and the differences in the measurement of explanatory variables. Our primarily meta-analytic findings show that there is a significant positive association between board size, board composition, audit committee and voluntary disclosure, while CEO duality has a significant negative effect on voluntary disclosure. Our sub-group meta-analytic results provide evidence that country geographic location moderates the association between board size, board composition, CEO duality and voluntary disclosure. In addition, disclosure type, disclosure method and the level of investor protection moderate the association between voluntary disclosure and CEO duality. Finally, differences in the definition of the explanatory variables moderate the association between board composition and voluntary disclosure. Our sensitivity analysis with respect to the time period provides evidence that, prior to 2002, CEO duality has a significantly negative association with voluntary disclosure. However, for the period following 2002, CEO duality has an insignificant effect on voluntary disclosure. 
Overall, our meta-analytic findings emphasize the need to explicitly consider the country geographic location when one analyzes the association between board characteristics and voluntary disclosure. In addition, the negative effect of CEO duality on voluntary disclosure is more pronounced in high investor protection settings implying that the litigation process, in high quality judicial systems, reduces managers' incentives to disclose information.

One limitation of our results is the 'apples and oranges' problem caused by the wide range of econometric methodologies used to estimate the effect size. However, recent accounting literature applied largely meta-analysis and our analysis is in line with previous meta-analyses (e.g. García-Meca \& Sánchez-Ballesta, 2010). In addition, the meta-analysis technique represents a simple test of the association between two variables and it does not allow us to control for endogeneity or reverse causality if the primary study does not control such an issue. Since the empirical disclosure studies, included in our meta-analysis, do not address this issue, we find it impossible to control for endogeneity.

Several avenues for future research exist. Firstly, there is a need for more research on the problem of endogeneity between voluntary disclosure and corporate governance. Secondly, since virtually all studies dealing with the impact of corporate governance on voluntary disclosure eliminate financial companies from their samples, it will be interesting to study explicitly, for financial companies, the impact of corporate governance on voluntary disclosure to see if there is a significant difference from those of non-financial companies. Finally, the association between the voluntary disclosure of executive compensation and board characteristics represents an interesting field of future research. 


\section{References}

*Studies included in the meta-analysis.

*Abdelsalam, O.H., \& Street, D.L. (2007). Corporate governance and the timeliness of corporate internet reporting by UK listed companies. Journal of International Accounting, Auditing and Taxation, 16, 111-130.

*Abeysekera, I. (2010). The influence of board size on intellectual capital disclosure by Kenyan listed firms. Journal of Intellectual Capital, 11 (4), 504-518.

*Adams, M., \& M. Hossain. (1998). Managerial discretion and voluntary disclosure: Empirical evidence from the New Zealand life industry. Journal of Accounting and Public Policy, 17, 245-281.

Adams, R. B., Licht, A. N., \& Sagiv, L. (2011). Shareholders and stakeholders: how do directors decide?. Strategic Managemen. Journal. 32, 1331-1355.

*Adebimpe, U. \& Peace, O. (2011). Corporate governance, companies attributes and voluntary disclosures: a study of Nigerian listed companies. International Journal of Computer and Application in Management. 1(2), 20-29.

Ahmed, K., \& Courtis, J.K. (1999). Associations between corporate characteristics and disclosure levels in annual reports: a meta-analysis. The British Accounting Review, 31 (1), 35-61.

*Akhtaruddin, M., \& Haron, H. (2010). Board ownership, audit committees' effectiveness and corporate voluntary disclosures. Asian Review of Accounting, 18 (1): 68-82.

*Al-Janadi, Y., Abdul Rahman, R., \& Omar, N. (2013). Corporate governance mechanisms and voluntary disclosure in Saudi Arabia. Research Journal of Finance and Accounting, 4 (4), 25-35.

*Allegrini, M., \& Greco, G. (2013). Corporate boards, audit committees and voluntary disclosure: evidence from Italian listed companies. Journal of Management and Governance, 17 (1), 187-216.

*Al-Shammari, B., \& Al-Sultan, W. (2010). Corporate governance and voluntary disclosure in Kuwait. International Journal of Disclosure and Governance, 7 (3), 262- 280.

*Apostolou, A.K., \& Nanopoulos, K.A. (2009). Voluntary accounting disclosure and corporate governance: evidence from Greek listed firms. Int. J. Accounting and Finance, 1 (4), 395-414.

*Arcay, M. B., \& Vazquez, M. M. (2005). Corporate characteristics, governance rules and the extent of voluntary disclosure in Spain. Advances in Accounting, 21, 299-331.

Artiach, T. C, \& Clarkson, P M (2011). Disclosure, conservatism and the cost of equity capital: A review of the foundation literature. Accounting \& Finance, 51, 2-49.

Anderson, C. A. \& Anthony, R. N. (1986). The new corporate directors: Insights for board members and executives (New York: Whiley).

Anderson, R. Mansi, S. \& Reeb, D. (2004). Board characteristics, accounting report integrity, and the cost of debt. Journal of Accounting and Economics, 37 (3), 315-342. 
Ayuso, S., \& Argandoña, A. (2007). Responsible corporate governance: Towards a stakeholder board of directors? (IESE Business School Working Paper No. 701). Retrieved December 10, 2013, from http://www.iese.edu/research/pdfs/DI-0701-E.pdf.

*Baek, Johnson, and Kim. (2009). Managerial ownership, corporate governance and voluntary disclosure. Journal of Business and Economic Studies, 15 (2), 44-61.

*Barako, D. G. \& Brown, A. (2008). Corporate social reporting and board representation: evidence from the Kenyan banking sector. Journal of Management and Governance, 12, 309324.

*Barako, D.G., Hancock, P., \& Izan, H.Y. (2006). Factors influencing voluntary corporate disclosure by Kenyan companies. Corporate Governance: An International Review, 14 (2), 107-125.

*Barros, C., Boubaker, S., \& Hamrouni, A. (2013). Corporate governance and voluntary disclosure in France. The Journal of Applied Business Research, 29 (2), 561-578.

Beretta, S., \& Bozzolan, S. (2004). A framework for the analysis of firm risk communication. The International Journal of Accounting, 39, 265-288.

Blue Ribbon Report. (1999). Report and recommendations of the blue ribbon committee on improving the effectiveness of corporate audit committees. New York: New York Stock Exchange and the National Association of Securities Dealers.

Boone, A., Field, L., Karpoff, J., \& Raheja, C., (2007). The determinants of corporate board size and independence: an empirical analysis. Journal of Financial Economics, 85, 65-101.

*Brammer, S., \& Pavelin, S. (2006). Voluntary environmental disclosures by large UK companies. Journal of Business Finance \& Accounting, 33 (7 \& 8), 1168-1188.

Bravo F, Abad M C, Trombetta M (2010). Disclosure indices design: does it make a difference? Spanish Accounting Review, 12 (2): 253-277.

*Boesso, G., \& Kumar, K. (2007). Drivers of corporate voluntary disclosure: a framework and empirical evidence from Italy and the United States. Accounting, Auditing and Accountability Journal. 20 (2), 269 - 296.

Brown, P., Beekes, W., \& Verhoeven, P. (2011). Corporate governance, accounting and finance: A review. Accounting and Finance, 51, 96-172.

*Bujaki, M., \& McConomy, B. (2002). Corporate governance: Factors influencing voluntary disclosure by publicly traded Canadian firms. Canadian Accounting Perspectives, 1 (2), 105139.

*Buniamin, S., Alrazi, B., Johariand, N., \& Rahman, N. (2008). An investigation of the association between corporate governance and environmental reporting in Malaysia. Asian Journal of Business and Accounting, 1(2), 65-88

*Cerbioni, F., \& and Parbonetti, A. (2007). Exploring the effects of corporate governance on intellectual capital disclosure: An analysis of European biotechnology companies. European Accounting Review. 16 (4), 791-826.

*Chau, G., \& Gray, S. J. (2010). Family ownership, board independence and voluntary disclosure: Evidence from Hong Kong. Journal of International Accounting, Auditing and Taxation. 19, 93-109. 
*Chen, C. J. P., \& Jaggi, B. (2000). Association between independent non-executive directors, family control and financial disclosures in Hong Kong. Journal of Accounting and Public Policy, 19,285-310.

*Cheng, E.C.M., \& Courtenay, S.M. (2006). Board composition, regulatory regime and voluntary disclosure. International Journal of Accounting, 41(3), 262-289.

Core, J. (2001). A review of the empirical disclosure literature: discussion, Journal of Accounting and Economics, 31, 441-456.

*Cormier, D., Aerts, W., Ledoux, M.-J., \& Magnan, M. (2009). Attributes of social and human capital disclosure and information asymmetry between managers and investors. Canadian Journal of Administrative Sciences, 26, 71-88.

*Cormier, D., Ledoux, M.-J., \& Magnan, M. (2012). The moderating effect of voluntary disclosure on the relation between earnings quality and information asymmetry: some Canadian evidence. Internatioanl Journal of Accounting, Auditing and Performance Evaluation, 8(2), $157-183$.

Dalton, D. R., Daily, C. M, Johnson, J. L., \& Ellstrand, A. E. (1999). Number of directors and financial performance: a meta-analysis. Academy of Management Journal, 42(6), 674 686.

Demb, A., \& Neubauer, F. F. (1992). The corporate board, Oxford University Press, Oxford. *Donnelly, R., \& Mulcahy, M. (2008). Board structure, ownership, and voluntary disclosure in Ireland. Corporate Governance: An International Review, 16 (5), 416-429.

*Eng, L., \& Mak, Y. (2003). Corporate governance and voluntary disclosure. Journal of Accounting and Public Policy, 22, 325-345.

*Ezat, A., \& El-Masry, A. (2008). The impact of corporate governance on the timeliness of corporate internet reporting by Egyptian listed companies. Managerial Finance, 34 (12), 848867.

Fama, E., \& Jensen, M. C. (1983). Separation of ownership and control. Journal of Law and Economics, 26, 301-325.

*Felo, A. J. (2010). Corporate reporting transparency, board independence and expertise, and CEO duality. http://papers.ssrn.com/sol3/papers.cfm?abstract_id=1373942.

*Gandía, J. L. (2008). Determinants of internet-based corporate governance disclosure by Spanish listed companies. Online Information Review, 32 (6), 791-817.

García-Meca, E., \& Sánchez-Ballesta, J.P. (2010). The association of board independence and ownership concentration with voluntary disclosure: a meta-Analysis. European Accounting Review, 19, 603- 627.

Gelb, D. S., \& Zarowin, P. (2002). Corporate disclosure policy and the informativeness of stock prices. Review of Accounting Studies, 7 (1), 33-52.

*Ghazali , N ., \& Weetman , P . (2006). Perpetuating traditional influences: Voluntary disclosure in Malaysia. Journal of International Accounting Auditing and Taxation. 15 (2), $226-248$.

Gregory, H. J. (2009). Comparison of corporate governance guidelines and codes of best practices. Available at: http://www.weil.com/files/Publication/1c418175-0e4c-47ac-934197df376b5ae2/Presentation/. 
*Gul, F., \& Sidney Leung, S. (2004). Board leadership, outside directors_expertise and voluntary corporate disclosures. Journal of Accounting and Public Policy, 23, 351- 379.

*Halme, M., \& Huse, M. (1997). The influence of corporate governance, industry and country factors on environmental reporting. Scand. J. Mgmt, 13 (2),137-157,

*Haniffa, R. M., \& Cooke, T. E. (2002). Culture, corporate governance and disclosure in Malaysian corporations. Abacus, 38 (3), 317-349.

*Haniffa, R. M., \& Cooke, T.E. (2005). The impact of culture and governance on corporate social reporting. Journal of Accounting and Public Policy, 24, 391- 430.

Herman, E. S. (1981). Corporate Control, Corporate Power, New York: Cambridge University Press.

Hermalin, B. E., \& Weisbach, M. S. (2003). Boards of directors as an endogenously determined institution: a survey of the economic literature. FRBNY Economic Policy Review, April, 7-26.

*Hidalgo, R., García-Meca, E. \& Martínez, I. (2011). Corporate governance and intellectual capital disclosure. Journal of Business Ethics, 100 (3), 483-495.

*Ho, S. S. M., \& Wong, K. S. (2001). A Study of the relationship between corporate governance structures and the extent of voluntary disclosure. Journal of International Accounting, Auditing and Taxation. 10 (2), 139-156.

*Huafang, X., \& Jianguo, Y. (2007). Ownership structure, board composition and corporate voluntary disclosure: evidence from listed companies in China. Managerial Auditing Journal, 22 (6), 604-619.

Huffcutt, A., \& Arthur. W. (1995). Development of a new outlier statistic for meta-analytic data. Journal of Applied Psychology, 80 (2), 327-334.

Hunter, J. E., \& Schmidt, F. L. (1990). Methods of meta-analysis: Correcting error and bias in research findings. Newbury Park, CA: Sage.

Hunter, J. E., \& Schmidt, F. L. (2000). Fixed effects vs. random effects meta-analysis models: implications for cumulative knowledge in Psychology. International Journal of Selection and Assessment, 8, 275-292.

Hunter, J.E., Schmidt, F.L., \& Jackson, G.B. (1982). Cumulating Research Findings Across Studies. Studying Organizations: Innovations in Methodology 4, Beverly Hill: Sage.

*Juini, F. (2013). Corporate governance and the level of financial disclosure by Tunisian firm. Journal of Business Studies Quarterly, 4 (3), 95-111.

*Kelton, A.S., \& Yang, Y. (2008). The impact of corporate governance on internet financial reporting. Journal of Accounting and Public Policy, 27(1), 62-87.

*Khan, H. (2010). The effect of corporate governance elements on corporate social responsibility (CSR) reporting: empirical evidence from private commercial banks of Bangladesh. International Journal of Law and Management, 52 (2), 82 - 109. 
*Khan, A., Muttakin, M., \& Siddiqui, J. (2013). Corporate governance and corporate social responsibility disclosures: evidence from an emerging economy. Journal of Business Ethics, $114(2), 207-223$.

Khlif, H., \& Souissi, M. (2010). The determinants of corporate disclosure: A meta-analysis. International Journal of Accounting and Information Management, 18 (3), 198-219.

*Khodadadi, V. Khazami, S., \& Aflatooni, A. (2010). The effect of corporate governance structure on the extent of voluntary disclosure in Iran. Business Intelligence Journal, 3(2), 151-164.

Kim, K Al-Shammari, H, Bongjin Kim, B., \& Lee, S. (2008). CEO duality leadership and corporate diversification behaviour, Journal of Business Research, 62 (11), 1173-1180.

Laksmana, I. (2008). Corporate board governance and voluntary disclosure of executive compensation practices. Contemporary Accounting Research, 25(4), 1147-1182.

La Porta, R, F. Lopez-de-Silanes, A. Shleifer, and Vishny, R. (1998). Law and Finance. Journal of Political Economy, 106 (6), 1113.

*Li, J., Pike, R., \& Haniffa, R. (2008). Intellectual capital disclosure and corporate governance structure in UK firms. Accounting and Business Research, 38 (2), 137-159.

*Li, J., Pike, R., \& Haniffa, R. (2012). The effect of audit committee characteristics on intellectual capital disclosure, The British Accounting Review, 44, 98-110.

Lipton, M. and Lorsh, J.W. (1992), A modest proposal for improved corporate governance, Business Lawyer, 48 (1), 59-77.

*Lim, S., Matollcky, Z., \& Chow, D. (2007). The association between board composition and different types of voluntary disclosure, European Accounting Review, 16, 555-583.

*Lim, Y.Z., Talha, M., Mohamed, J., \& Sallehhuddin, A. (2008). Corporate social responsibility disclosure and corporate governance in Malaysia, International. Journal of Behavioural Accounting and Finance, 1 (1), 67-89.

*Mallin, C., Michelon, G., \& Raggi, D. (2013). Monitoring intensity and stakeholders' orientation: how does governance affect social and environmental disclosure?. Journal of Business Ethics, 114 (1), 29-43.

*Mangena, M. \& Pike, R. (2005). The effect of audit committee shareholding, financial expertise and size on interim financial disclosures. Accounting and Business Research, 35 (4), 327-349.

*Mangena, M., \& Tauringana, V. (2007). Disclosure, corporate governance and foreign share ownership on the Zimbabwe stock exchange. Journal of International Financial Management \& Accounting, 18 (2), 53-85.

Marston, C.L. \& Shrives, P.J. (1991). The use of disclosure indices in accounting research: A review article. British Accounting Review, 25, 195-210. 
Meek, G.K., Roberts, C.B., \& Gray, S.J. (1995). Factors influencing voluntary annual report disclosures by US, UK and Continental European multinational corporations, Journal of International Business Studies, 3rd quarter, 555-572.

*Mert, E. (2011). The impact of corporate governance on internet financial reporting: evidence from Turkey. International Journal of Business Research, 11(3): available at: http://www.highbeam.com/doc/1G1-272511073.html.

*Michelon, G., \& Parbonetti, A. (2012). The effect of corporate governance on sustainability disclosure. Journal of Management and Governance, 16 (3), 477 - 509.

*Mohamad, W., \& Sulong, Z. (2010). Corporate governance mechanisms and extent of disclosure: Evidence from listed companies in Malaysia. International Business Research, 3 (4). 216-228.

Moller, A., \& M. Jennions. (2001). Testing and adjusting for publication bias. Trends in Ecology Evolution, 16, 580-586.

*Nor, H., Saleh,N.M., Jaffar, R., \& Shukor, Z. A. (2010). Corporate governance and R\&D reporting in Malaysian MESDAQ market, International Journal of Economics and Management. 4(2). 350-372.

Orwin, R. G. (1983). A fail-safe N for effect size in meta-analysis. Journal of Educational Statistics, 8,157-159.

*Patelli, L., \& Prencipe, A (2007). The Relationship between voluntary disclosure and independent directors in the presence of a dominant shareholder. European Accounting Review, 16(1), 5-33.

Pfeffer J. (1981). Power in organizations. Marshfield, MA: Pitman.

Pincus, K., Rusbarsky, M., \& Wong, J. (1989). Voluntary Formation of Corporate Audit Committees among NASDAQ Firms. Journal of Accounting and Public Policy, 8 (4) 239265.

Pomeroy, B., \& Thornton, D. (2008). Meta-analysis and the accounting literature: The case of audit committee independence and financial reporting quality. European Accounting Review, 17, 305-330.

*Prado-Lorenzo, J., \& Garcia-Sanchez, I. (2010). The role of the board of directors in disseminating relevant information on Greenhouse Gases. Journal of Business Ethics, 97, 391- 424.

Rhoades, D.L., Rechner, P. L., \& Sudramurthy, C. (2001), A meta-analysis of board directorship structure and financial performance: are "two heads better than one"?', Corporate Governance: An International Review, 9, 311-19.

Rogers, J.L., \& Van Buskirk, A. (2009). Shareholder litigation and changes in disclosure behavior. Journal of Accounting and Economics, 47, 136-156.

Rosenthal, R. (1991). Meta-analytic procedures for social research. Applied social research methods series, 6, Newbury Park: Sage.

*Rouf, A. (2011). Corporate characteristics, governance attributes and the extent of voluntary disclosure in Bangladesh. African Journal of Business Management, 5(19), 7836-7845. 
*Said, R., Zainuddin, Y. H., \& Haron, H. (2009). The relationship between corporate social responsibility disclosure and corporate governance characteristics in Malaysian public listed companies. Social Responsibility Journal, 5 (2), 212 - 226.

*Samaha, K., \& Abdallah, S. (2012). Further evidence on web-based corporate disclosures in developed versus developing countries: A comparative analysis of nature and determinants in Egypt and the United Kingdom. International Journal of Disclosure and Governance, 9 (2), $148-180$.

*Samaha, K., \& Dahawy, K. (2011). An empirical analysis of corporate governance structures and voluntary corporate disclosure in volatile capital markets: The Egyptian experience. International Journal of Accounting, Auditing and Performance Evaluation, 7 (1/2), 61-93.

*Samaha, K., Dahawy, K., Abdel-Meguid, A., \& Abdallah, S. (2012). Propensity and comprehensiveness of corporate internet reporting in Egypt: Do board composition and ownership structure matter? International Journal of Accounting and Information Management, 20 (2), 142 - 170.

*Siregar, S. V., \& Bachtiar, Y. (2010). Corporate social reporting: Empirical evidence from Indonesia Stock Exchange. International Journal of Islamic and Middle Eastern Finance and Management, 3 (3), 241 - 252.

Smith Report (2003). Audit Committees: Combined Code Guidance, London: Financial Reporting Council. URL: www.frc .org .uk/publications.

Wang, J., \& Dewhirst, H.D. (1992). Boards of directors and stakeholder orientation, Journal of Business Ethics, 11 (2), 115-21.

Wang, M., \& Hussainey, K. (2013). Voluntary forward-looking statements driven by corporate governance and their value relevance. Journal of Accounting and Public Policy, 32 (3), 26-49.

*White, G., Lee, A., \& Tower, G. (2007). Drivers of voluntary intellectual capital disclosure in listed biotechnology companies. Journal of Intellectual Capital, 8 (3), 517- 537.

World Bank (2009). Report on the Observance of Standards and Codes: Accounting and Auditing, Arab Republic of Egypt, August.

*Xiao, J.Z., Yang H., \& Chow, C.W. (2004). The determinants and characteristics of voluntary-based disclosures by listed Chinese companies. Journal of Accounting and Public Policy, 23 (3), 191- 225.

*Yap, K., Saleh, Z., \& Abessi, M. (2011). Internet financial reporting and corporate governance in Malaysia. Australian Journal of Basic and Applied Sciences, 5(10), 1273-1289.

Table 1. Sample selection

\begin{tabular}{ll}
\hline Initial sample & 96 \\
\hline Criteria leading to exclusion of studies: & \\
- & Studies providing only descriptive statistics \\
- $\quad$ Other measures of disclosure & $(3)$ \\
- $\quad \begin{array}{l}\text { CG variables not included in our meta-analysis (e.g. ownership } \\
\text { attributes) }\end{array}$ & $(27)$ \\
\hline = Final sample & 64 \\
\hline
\end{tabular}


Table 2. Studies included in the meta-analysis

\begin{tabular}{|c|c|c|c|c|c|c|c|c|c|}
\hline \multirow{2}{*}{ Studies } & \multirow{2}{*}{ Country } & \multirow{2}{*}{$\begin{array}{l}\text { No } \\
\text { of firms }\end{array}$} & \multirow{2}{*}{$\begin{array}{l}\text { Reporting } \\
\text { years }\end{array}$} & \multirow{2}{*}{$\begin{array}{l}\text { Disclosure } \\
\text { proxy }\end{array}$} & \multirow{2}{*}{$\begin{array}{l}\text { Number } \\
\text { of items }\end{array}$} & \multicolumn{4}{|c|}{ Effect size (Pearson's coefficient) } \\
\hline & & & & & & BOS & $\mathrm{BCOM}$ & CEOD & $\mathrm{AC}$ \\
\hline Halme \& Huse (1997) & $\overline{\mathrm{SC}}$ & 140 & 1992 & CSED & 3 & 0.140 & & & \\
\hline Adams \& Hossain (1998) & New Zealand & 34 & 1988-1993 & TS & 189 & & 0.377 & & \\
\hline Chen \& Jaggi (2000) & Hong Kong & 87 & 1993-1994 & TS & 30 & & 0.156 & & \\
\hline Ho \& Wong (2001) & Hong Kong & 98 & 1997 & TS & 20 & & 0.108 & & 0.210 \\
\hline Haniffa \& Cooke (2002) & Malaysia & 167 & 1995 & TS & 65 & & 0.123 & 0.047 & \\
\hline Bujaki \& Mcconomy (2002) & Canada & 269 & 1997 & TS & 25 & & 0.223 & & \\
\hline Eng \& Mak (2003) & Singapore & 158 & 1995 & TS & 55 & & -0.157 & & \\
\hline Gul \& Leung (2004) & Hong Kong & 385 & 1996 & TS & 43 & & 0.102 & -0.141 & \\
\hline Xiao et al. (2004) & China & 300 & 2001 & IBD & 18 & & 0.150 & & \\
\hline Haniffa \& Cooke (2005) & Malaysia & 139 & 2002 & CSED & 41 & & -0.241 & & \\
\hline Arcay \& Vazquez (2005) & Spain & 91 & 1999 & TS & 18 & -0.038 & 0.306 & -0.168 & 0.383 \\
\hline Mangena \& Pike (2005) & UK & 262 & 2002 & TS & 113 & & 0.005 & & -0.097 \\
\hline Barako et al.(2006) & Kenya & 43 & 1993-2001 & TS & 47 & & -0.220 & -0.043 & 0.280 \\
\hline Brammer \& Pavelin (2006) & UK & 447 & 2000 & CSED & DV & & 0.093 & & \\
\hline Cheng \& Courtenay(2006) & Singapore & 104 & 2000 & TS & 72 & 0.256 & 0.278 & 0.085 & \\
\hline Ghazali \& Weetman (2006) & Malaysia & 87 & 2001 & CSED & 53 & & -0.137 & & \\
\hline Abdelsalem and Street (2007) & UK & 115 & 2006 & IBD & 11 & & -0.206 & 0.119 & \\
\hline Cerbioni \& Parbonetti (2007) & $\mathrm{SC}$ & 54 & 2002-2004 & ICD & 132 & 0.209 & 0.316 & 0.139 & \\
\hline Huafang \& Jianguo (2007) & China & 559 & 2002 & TS & 30 & & 0.103 & -0.082 & \\
\hline Boesso \& Kumur (2007) & Italy & 36 & 2002 & TS & 42 & & -0.050 & & \\
\hline Boesso \& Kumur (2007) & USA & 36 & 2002 & TS & 42 & & 0.260 & & \\
\hline Lim et al. (2007) & Australia & 181 & 2001 & CSED & 21 & 0.247 & 0.204 & & \\
\hline Mangena \& Tauringana (2007) & Zimbabwe & 51 & 2002 & TS & 86 & 0.322 & 0.413 & & 0.361 \\
\hline Patelli \& Prencipe (2007) & Italy & 171 & 2002 & TS & 74 & & 0.248 & & \\
\hline White et al. (2007) & Australia & 96 & 2005 & ICD & 78 & & 0.238 & & \\
\hline Barako \& Brown (2008) & Kenya & 40 & 2005 & CSED & 22 & & 0.272 & & \\
\hline Buniamin et al. (2008) & Malaysia & 243 & 2005 & CSED & $\mathrm{DV}$ & 0.148 & 0.102 & -0.050 & \\
\hline Donnelly \& Mulcahy (2008) & Ireland & 51 & 2002 & TS & 50 & 0.430 & 0.340 & & \\
\hline Ezat \& El-masry (2008) & Egypt & 50 & 2006 & IBD & 11 & 0.305 & 0.262 & -0.128 & \\
\hline Gandia (2008) & Spain & 92 & 2003 & IBD & 32 & 0.481 & & & \\
\hline Kelton \& Yang (2008) & USA & 284 & 2003 & IBD & 36 & & 0.179 & -0.056 & \\
\hline Li et al. (2008) & UK & 100 & 2005 & ICD & 61 & & 0.340 & -0.073 & 0.511 \\
\hline Lim et al. (2008) & Malaysia & 743 & 2003 & CSED & 27 & & 0.194 & -0.082 & \\
\hline Apostolou \& Nanopoulos & & & & & & & & & \\
\hline$(2009)$ & Greece & 72 & 2004 & TS & 56 & & 0.338 & & \\
\hline Baek et al .(2009) & USA & 374 & 2000 & TS & 99 & & 0.113 & & \\
\hline Cormier et al. (2009) & Canada & 155 & 2005 & $\mathrm{ICD}$ & 16 & 0.194 & 0.149 & & 0.165 \\
\hline Said et al. (2009) & Malaysia & 150 & 2006 & CSED & 41 & 0.232 & -0.011 & -0.055 & 0.153 \\
\hline Abeysekera (2010) & Kenya & 26 & $2002-03$ & ICD & 5 & 0.064 & 0.218 & & \\
\hline Akhtaruddin \& Haron (2010) & Malaysia & 124 & 2003 & TS & 64 & & & & 0.120 \\
\hline Al-Shammari \& Al-Sultan & Kuwait & & & & & & & & \\
\hline$(2010)$ & & 170 & 2007 & TS & 76 & & 0.043 & -0.054 & 0.155 \\
\hline Chau \& Gray (2010) & Hong Kong & 273 & 2002 & TS & 85 & & 0.207 & -0.267 & \\
\hline Fleo $(2010)$ & USA & 429 & 2001 & TS & 98 & 0.192 & 0.174 & -0.107 & \\
\hline Khan (2010) & Bangladesh & 30 & 2007-2008 & CSED & 60 & & 0.550 & & \\
\hline Khodadadi et al. (2010) & Iran & 106 & $2001-2005$ & TS & 33 & & -0.007 & -0.034 & \\
\hline Mohamad \& Sulong (2010) & Malaysia & 40 & $2003 \& 2006$ & TS & 40 & & 0.113 & -0.115 & 0.145 \\
\hline Nor et al. (2010) & Malaysia & 93 & $2005-2006$ & $\mathrm{ICD}$ & DV & & -0.023 & -0.088 & \\
\hline $\begin{array}{l}\text { Prado-Lorenzo \& Garcia- } \\
\text { Sanchez (2010) }\end{array}$ & $\mathrm{SC}$ & 283 & 2007 & CSED & 27 & 0.061 & -0.044 & -0.163 & \\
\hline Siregar \& Bachtiar (2010) & Indonesia & 87 & 2003 & CSED & 41 & 0.200 & & & \\
\hline Adebimpe \& Peace (2011) & Nigeria & 48 & 2008 & TS & 60 & 0.302 & 0.051 & & \\
\hline Hidalgo et al. (2011) & Mexico & 100 & 2005-2007 & ICD & 58 & 0.220 & 0.070 & 0.010 & 0.210 \\
\hline Mert (2011) & Tuerky & 173 & 2009 & IBD & 60 & 0.037 & 0.148 & & \\
\hline Rouf (2011) & Bangladesh & 120 & 2008 & TS & 105 & 0.339 & 0.232 & 0.482 & 0.468 \\
\hline Samaha \& Dahawy (2011) & Egypt & 100 & 2006 & TS & 80 & & 0.497 & & 0.703 \\
\hline Yap, Saleh \& Abessi (2011) & Malaysia & 254 & 2008 & IBD & 270 & 0.182 & 0.161 & 0.062 & 0.122 \\
\hline Cormier et al. (2012) & Canada & 136 & 2005 & IBD & 100 & 0.340 & 0.020 & -0.110 & 0.260 \\
\hline Li et al. (2012) & UK & 100 & 2005 & ICD & 61 & & 0.340 & & 0.216 \\
\hline Michelon \& Parbonetti (2012) & $\mathrm{SC}$ & 114 & 2003 & CSED & 178 & 0.217 & 0.076 & -0.076 & \\
\hline Samaha \& Abdallah (2012) & Egypt & 99 & 2011 & IBD & DV & & 0.268 & 0.292 & 0.199 \\
\hline Samaha et al. 2012 & Egypt & 100 & 2008 & IBD & 72 & -0.128 & -0.164 & -0.041 & \\
\hline Allegrini \& Greco (2013) & Italy & 177 & 2007 & TS & 60 & 0.400 & 0.226 & -0.238 & 0.061 \\
\hline Al-Janadi et al. (2013) & Saudi Arabia & 87 & 2006 & TS & 21 & 0.270 & 0.417 & 0.275 & 0.107 \\
\hline Barros et al. (2013) & France & 206 & 2006-2009 & TS & 112 & & 0.024 & & 0.057 \\
\hline Juini (2013) & Tunisia & 22 & 2004-2009 & TS & 57 & 0.021 & -0.066 & -0.204 & \\
\hline Khan et al. (2013) & Bangladesh & 116 & $2005-2009$ & CSED & 20 & & 0.269 & 0.003 & 0.325 \\
\hline Mallin et al (2013) & USA & 135 & $2005-2007$ & CSED & 121 & & 0.073 & -0.071 & \\
\hline
\end{tabular}

Notes: TS: total score; CSED: corporate social and environmental disclosure; ICD: intellectual capital disclosure; IBD: internetbased disclosure. BOS: board size; BCOM: board composition; CEOD: CEO duality; AC: audit committee. DV: Dummy variable: 1 if the firm makes such a disclosure and 0 otherwise; SC: several countries. 
Table 3. Board size, board composition and voluntary disclosure

\begin{tabular}{|c|c|c|c|c|c|c|c|c|c|c|}
\hline & $\begin{array}{l}\text { Sample } \\
\text { (N) }\end{array}$ & $\begin{array}{l}\text { Number } \\
\text { of studies } \\
\text { (K) }\end{array}$ & $\begin{array}{l}\text { Mean } \\
\text { correlation } \bar{r}\end{array}$ & $\begin{array}{l}\text { Observed } \\
\text { variance } S_{r}^{2}\end{array}$ & $\begin{array}{l}\text { Estimated error } \\
\text { variance } S_{e}^{2}\end{array}$ & $\begin{array}{l}\text { Percentage explained } \\
S_{e}^{2} / S_{r}^{2}\end{array}$ & Z-statitic & $95 \%$ confidence interval & $\chi_{K-1}^{2}$ & $\begin{array}{l}\text { File- } \\
\text { drawer }\end{array}$ \\
\hline \multicolumn{11}{|l|}{ Board size $(A)$} \\
\hline $\begin{array}{l}\text { Overall meta-analysis } \\
\text { Moderating factors }\end{array}$ & 3945 & 27 & $0.193 * * *$ & 0.015 & 0.006 & 41.659 & 8.137 & $0.146 ; 0.239$ & $64.810^{* *}$ & 33 \\
\hline TS & 1290 & 10 & $0.229 * * *$ & 0.017 & 0.007 & 40.076 & 5.509 & $0.147 ; 0.311$ & $12.927 * *$ & 17 \\
\hline CSED & 1198 & 7 & $0.162 * * *$ & 0.004 & 0.004 & 100.000 & 6.329 & $0.112 ; 0.212$ & 5.817 & 6 \\
\hline ICD & 652 & 4 & $0.198 * * *$ & 0.001 & 0.005 & 100.000 & 9.693 & $0.112 ; 0.212$ & 1.190 & 5 \\
\hline $\begin{array}{l}\text { IBD } \\
\text { Annual reports } \\
\text { Disclosure checklist } \\
\text { Number of directors } \\
\text { Dummy variable }\end{array}$ & $\begin{array}{r}805 \\
3140 \\
3702 \\
3802 \\
203\end{array}$ & $\begin{array}{r}6 \\
21 \\
26 \\
25 \\
2\end{array}$ & $\begin{array}{l}0.176 * * \\
0.197 * * * \\
0.192 * * * \\
0.200 * * * \\
-0.001\end{array}$ & $\begin{array}{l}0.034 \\
0.010 \\
0.015 \\
0.014 \\
0.002\end{array}$ & $\begin{array}{l}0.007 \\
0.006 \\
0.006 \\
0.006 \\
0.013\end{array}$ & $\begin{array}{c}20.145 \\
60.956 \\
42.249 \\
42.549 \\
100.000\end{array}$ & $\begin{array}{l}2.318 \\
8.956 \\
8.152 \\
8.403 \\
-0.026\end{array}$ & $\begin{array}{l}0.027 ; 0.365 \\
0.154 ; 0.240 \\
0.150 ; 0.245 \\
0.153 ; 0.247 \\
-0.068 ; 0.067\end{array}$ & $\begin{array}{l}29.783^{* * *} \\
34.450^{* * * *} \\
61.538^{* * * *} \\
58.755^{* * *} \\
0.344\end{array}$ & $\begin{array}{r}4 \\
27 \\
31 \\
38 \\
-\end{array}$ \\
\hline $\begin{array}{l}\text { High protection } \\
\text { Low protection }\end{array}$ & $\begin{array}{l}1729 \\
1534\end{array}$ & $\begin{array}{l}10 \\
13\end{array}$ & $\begin{array}{l}0.224 * * * \\
0.183^{* * *}\end{array}$ & $\begin{array}{l}0.005 \\
0.027\end{array}$ & $\begin{array}{l}0.005 \\
0.008\end{array}$ & $\begin{array}{c}100.000 \\
27.207\end{array}$ & $\begin{array}{l}10.246 \\
3.878\end{array}$ & $\begin{array}{l}0.267 ; 0.181 \\
0.090 ; 0.276\end{array}$ & $\begin{array}{l}9.217 \\
49.780^{* * *}\end{array}$ & $\begin{array}{l}16 \\
15\end{array}$ \\
\hline $\begin{array}{l}\text { High income OCDE } \\
\text { MENA } \\
\text { Sub-Saharan African } \\
\text { East Asia \& Pacific }\end{array}$ & $\begin{array}{c}1457 \\
369 \\
151 \\
958 \\
\end{array}$ & $\begin{array}{l}9 \\
4 \\
3 \\
6 \\
\end{array}$ & $\begin{array}{l}0.252^{* * * *} \\
0.068 \\
0.226 * * * \\
0.210^{* * *} \\
\end{array}$ & $\begin{array}{l}0.014 \\
0.032 \\
0.013 \\
0.002 \\
\end{array}$ & $\begin{array}{l}0.005 \\
0.011 \\
0.017 \\
0.005 \\
\end{array}$ & $\begin{array}{r}36.948 \\
39.936 \\
100.000 \\
100.000 \\
\end{array}$ & $\begin{array}{l}6.224 \\
0.753 \\
3.321 \\
8.617 \\
\end{array}$ & $\begin{array}{l}0.172 ; 0.331 \\
-0.109 ; 0.245 \\
0.092 ; 0.360 \\
0.162 ; 0.258 \\
\end{array}$ & $\begin{array}{c}24.358 * * * \\
12.144 * * * \\
2.347 \\
3.756 \\
\end{array}$ & $\begin{array}{r}19 \\
- \\
5 \\
9 \\
\end{array}$ \\
\hline \multicolumn{11}{|l|}{ Board composition (B) } \\
\hline $\begin{array}{l}\text { Overall meta-analysis } \\
\text { Moderating factors }\end{array}$ & 12628 & 61 & $0.115^{* * *}$ & 0.022 & 0.005 & 21.594 & 6.096 & $0.078 ; 0.152$ & $194.498 * * *$ & 19 \\
\hline TS & 6728 & 31 & $0.100 * * *$ & 0.023 & 0.005 & 19.119 & 3.633 & $0.046 ; 0.154$ & $162.146^{* * *}$ & 5 \\
\hline CSED & 3258 & 13 & $0.139 * * *$ & 0.021 & 0.004 & 18.165 & 3.465 & $0.060 ; 0.218$ & $71.564 * * *$ & 8 \\
\hline ICD & 1131 & 8 & $0.165^{* * *}$ & 0.017 & 0.007 & 38.964 & 3.565 & $0.074 ; 0.256$ & $20.529 * * *$ & 8 \\
\hline Annual reports & $\begin{array}{c}11117 \\
1511\end{array}$ & $\begin{array}{r}52 \\
9\end{array}$ & $\begin{array}{l}0.116^{* * *} \\
0.108 * *\end{array}$ & $\begin{array}{l}0.022 \\
0.017\end{array}$ & $\begin{array}{l}0.004 \\
0.006\end{array}$ & $\begin{array}{l}20.364 \\
33.210\end{array}$ & $\begin{array}{l}5.596 \\
2.469\end{array}$ & $0.075 ; 0.156$ & $206.237 * * *$ & 17 \\
\hline $\begin{array}{l}\text { IBD } \\
\text { Disclosure checklist }\end{array}$ & $\begin{array}{c}1511 \\
11651\end{array}$ & 57 & $\begin{array}{l}0.108^{* *} \\
0.125^{* * * *}\end{array}$ & $\begin{array}{l}0.017 \\
0.022\end{array}$ & $\begin{array}{l}0.006 \\
0.005\end{array}$ & $\begin{array}{l}33.210 \\
21.041\end{array}$ & $\begin{array}{l}2.469 \\
6.076\end{array}$ & $\begin{array}{l}0.022 ; 0.195 \\
0.081 ; 0.159\end{array}$ & $\begin{array}{l}27.099 * * * \\
199.604 * * *\end{array}$ & $\begin{array}{c}2 \\
24\end{array}$ \\
\hline Dummy variable & 977 & 4 & 0.046 & 0.007 & 0.004 & 56.496 & 1.100 & $-0.036 ; 0.130$ & $74.341^{* * * *}$ & - \\
\hline PID & 7404 & 35 & $0.137 * * *$ & 0.013 & 0.004 & 34.159 & 7.056 & $0.099 ; 0.176$ & $102.459 * * *$ & 21 \\
\hline PIND & 1497 & 9 & $0.167 * * *$ & 0.017 & 0.006 & 33.569 & 3.870 & $0.082 ; 0.252$ & $26.809 * * *$ & 9 \\
\hline PND & 3675 & 17 & 0.047 & 0.034 & 0.004 & 12.681 & 1.018 & $-0.043 ; 0.137$ & $126.169 * * *$ & - \\
\hline High protection & 6895 & 33 & $0.117^{* * * *}$ & 0.016 & 0.004 & 27.698 & 5.247 & $0.073 ; 0.161$ & $119.141 * * *$ & 11 \\
\hline Low protection & 5422 & 27 & $0.112^{* * *}$ & 0.026 & 0.004 & 18.990 & 3.561 & $0.050 ; 0.164$ & $149.173 * * *$ & 8 \\
\hline High income OCDE & 5258 & 25 & $0.134 * * *$ & 0.016 & 0.004 & 28.255 & 5.283 & $0.084 ; 0.184$ & $88.878 * * *$ & 14 \\
\hline MENA & 1341 & 8 & 0.059 & 0.021 & 0.006 & 28.075 & 1.161 & $-0.041 ; 0.160$ & $28.494 * * *$ & - \\
\hline Sub-Saharan African & 581 & 4 & -0.102 & 0.044 & 0.007 & 15.091 & -0.974 & $-0.331 ; 0.104$ & $26.505 * * *$ & - \\
\hline East Asia \& Pacific & 4911 & 20 & $0.125 * * *$ & 0.014 & 0.003 & 26.894 & 4.799 & $0.076 ; 0.182$ & $74.346 * * *$ & 9 \\
\hline
\end{tabular}

Notes: TS: total score; CSED; corporate social and environmental disclosure; ICD: intellectual capital disclosure; IBD: internet-based disclosure; (PID): percentage of independent directors;

(PIND): percentage of independent non-executive directors; (PND): percentage of non-executive directors; *p <.10; **p <.05; ***p <.01. 
Table 4. CEO duality, audit committee and voluntary disclosure

\begin{tabular}{|c|c|c|c|c|c|c|c|c|c|c|}
\hline & $\begin{array}{l}\text { Sample } \\
\text { (N) }\end{array}$ & $\begin{array}{l}\text { Number } \\
\text { of studies } \\
\text { (K) }\end{array}$ & $\begin{array}{l}\text { Mean } \\
\text { correlation } \\
\bar{r}\end{array}$ & $\begin{array}{l}\text { Observed } \\
\text { variance } S_{r}^{2}\end{array}$ & $\begin{array}{l}\text { Estimated error } \\
\text { variance } S_{e}^{2}\end{array}$ & $\begin{array}{l}\text { Percentage } \\
\text { explained } \\
S_{e}^{2} / S_{r}^{2}\end{array}$ & Z-statistic & $\begin{array}{l}95 \% \text { confidence } \\
\text { interval }\end{array}$ & $\chi_{K-1}^{2}$ & File-drawer \\
\hline \multicolumn{11}{|l|}{ CEO duality (C) } \\
\hline $\begin{array}{l}\text { Overall meta-analysis } \\
\text { Moderating factors }\end{array}$ & 7918 & 33 & $-0.053 * * *$ & 0.012 & 0.004 & 33.817 & -2.796 & $-0.091 ;-0.016$ & $97.581 * * *$ & 14 \\
\hline TS & 3814 & 15 & $-0.070^{*}$ & 0.019 & 0.004 & 19.906 & -1.950 & $-0.102 ; 0.000$ & $75.206 * * *$ & 4 \\
\hline CSED & 2334 & 7 & $-0.064 * * *$ & 0.002 & 0.003 & 100.000 & -3.441 & $-0.109 ;-0.027$ & 5.752 & 2 \\
\hline ICD & 732 & 4 & -0.001 & 0.006 & 0.005 & 83.124 & -0.020 & $-0.080 ; 0.078$ & 4.812 & - \\
\hline IBD & 1038 & 7 & -0.006 & 0.006 & 0.007 & 100.000 & -0.023 & $-0.064 ; 0.051$ & 6.318 & - \\
\hline Annual reports & 6880 & 26 & $-0.061 * * *$ & 0.013 & 0.003 & 29.308 & -2.748 & $-0.104 ;-0.017$ & $88.710 * * *$ & 8 \\
\hline Disclosure checklist & 7388 & 30 & $-0.053 * * *$ & 0.013 & 0.004 & 30.823 & -2.551 & -0.094: - -0.012 & $97.328 * * *$ & 12 \\
\hline Dummy variable & 530 & 3 & $-0.062 * * *$ & 0.000 & 0.005 & 100.000 & -5.428 & $-0.084 ;-0.039$ & 14.490 & 1 \\
\hline High protection & 3736 & 14 & $-0.081 * * *$ & 0.006 & 0.004 & 60.702 & -3.892 & $-0.122 ;-0.040$ & $23.063 * * *$ & 2 \\
\hline Low protection & 3640 & 16 & -0.024 & 0.016 & 0.004 & 26.871 & -0.762 & $-0.087 ; 0.038$ & $59.542 * * *$ & - \\
\hline High income OCDE & 1698 & 9 & $-0.072 * *$ & 0.010 & 0.005 & 51.982 & -2.167 & $-0.138 ;-0.007$ & $17.343 * * *$ & 2 \\
\hline MENA & 1168 & 7 & -0.031 & 0.011 & 0.006 & 52.510 & -0.761 & $-0.109 ; 0.048$ & $13.330 * * *$ & - \\
\hline East Asia \& Pacific & 3925 & 13 & -0.050 & 0.005 & 0.003 & 21.354 & -1.458 & $-0.117 ; 0.017$ & $60.878 * * *$ & - \\
\hline \multicolumn{11}{|l|}{ Audit committee (D) } \\
\hline $\begin{array}{l}\text { Overall meta-analysis } \\
\text { Moderating factors }\end{array}$ & 4565 & 22 & $0.199 * * *$ & 0.021 & 0.004 & 21.358 & 6.498 & $0.139 ; 0.260$ & $103.002 * * *$ & 28 \\
\hline TS & 2691 & 13 & $0.168 * * *$ & 0.026 & 0.004 & 17.304 & 3.741 & $0.082 ; 0.256$ & $75.124 * * *$ & 12 \\
\hline CSED & 730 & 2 & $0.289^{* * *}$ & 0.005 & 0.002 & 47.605 & 5.894 & $0.193 ; 0.385$ & $4.201 * * *$ & 5 \\
\hline ICD & 655 & 4 & $0.246 * * *$ & 0.013 & 0.005 & 41.437 & 4.318 & $0.134 ; 0.293$ & $9.653 * *$ & 8 \\
\hline IBD & 489 & 3 & $0.176^{* * *}$ & 0.003 & 0.006 & 100.000 & 5.091 & $0.108 ; 0.243$ & 1.866 & 3 \\
\hline Annual reports & 4076 & 19 & $0.202 * * *$ & 0.023 & 0.004 & 18.810 & 5.852 & $0.134 ; 0.270$ & $101.005^{* * * *}$ & 25 \\
\hline Disclosure checklist & 4466 & 21 & $0.199 * * *$ & 0.021 & 0.004 & 20.387 & 6.280 & $0.137 ; 0.262$ & $103.004 * * *$ & 27 \\
\hline DV & 1865 & 9 & $0.293 * * *$ & 0.019 & 0.004 & 20.758 & 6.332 & $0.202 ; 0.384$ & $43.356 * * *$ & 21 \\
\hline INDC & 1493 & 7 & $0.105^{* * *}$ & 0.005 & 0.004 & 96.476 & 4.039 & $0.054 ; 0.156$ & 7.255 & 2 \\
\hline NAC & 1207 & 6 & $0.171 * * *$ & 0.017 & 0.005 & 27.002 & 3.195 & $0.066 ; 0.277$ & $22.219 * * *$ & 7 \\
\hline High protection & 1709 & 11 & $0.160^{* * *}$ & 0.012 & 0.006 & 49.372 & 4.778 & $0.094 ; 0.266$ & $22.279 * * *$ & 9 \\
\hline Low protection & 2856 & 11 & $0.223 * * *$ & 0.024 & 0.003 & 14.281 & 4.750 & $0.131 ; 0.315$ & $77.022 * * *$ & 17 \\
\hline High income OCDE & 1842 & 8 & $0.123 * * *$ & 0.017 & 0.004 & 23.651 & 2.616 & $0.031 ; 0.216$ & $33.824 * * *$ & 4 \\
\hline MENA & 456 & 4 & $0.275 * *$ & 0.052 & 0.007 & 14.354 & 2.412 & $0.051 ; 0.499$ & $27.864 * * *$ & 9 \\
\hline Sub-Saharan African & 481 & 2 & $0.288^{* * *}$ & 0.001 & 0.003 & 100.000 & 16.365 & $0.254 ; 0.324$ & 0.355 & 5 \\
\hline East Asia \& Pacific & 1486 & 7 & $0.244 * * *$ & 0.012 & 0.004 & 33.739 & 5.713 & $0.157 ; 0.322$ & $20.747 * * *$ & 13 \\
\hline
\end{tabular}

Notes: TS: total score; CSED: corporate social and environmental disclosure; ICD: intellectual capital disclosure; IBD: internet-based disclosure. (DV): 1 if audit committee exists and 0 otherwise; (NAC): number of audit committee members; (INDC): percentage of independent directors in the audit committee. ${ }^{*} \mathrm{p}<.10$; ${ }^{* *} \mathrm{p}<.05 ; * * * \mathrm{p}<.01$. 
Table 5. Summary of meta-analytic findings

\begin{tabular}{|c|c|c|c|c|c|c|c|}
\hline Variables & $\begin{array}{l}\text { Overall association } \\
\left(\mathrm{H}_{1}-\mathrm{H}_{4}\right)\end{array}$ & $\begin{array}{c}\text { Disclosure type } \\
\mathrm{H}_{5}\end{array}$ & $\begin{array}{c}\text { Annual report vs } \\
\text { Website } \\
\mathrm{H}_{6}\end{array}$ & $\begin{array}{c}\text { Investor protection } \\
\mathrm{H}_{7}\end{array}$ & $\begin{array}{c}\text { Geographic } \\
\text { location } \\
\text { H8 }\end{array}$ & $\begin{array}{c}\text { Checklist vs Dummy } \\
\mathrm{H}_{9}\end{array}$ & $\begin{array}{c}\text { Measurement } \\
\text { of board } \\
\text { proxies } \\
\mathrm{H}_{10}\end{array}$ \\
\hline Board size & Yes & $\mathrm{NO}$ & $\mathrm{NO}$ & $\mathrm{NO}$ & YES & (1) & (1) \\
\hline Board composition & Yes & NO & NO & NO & YES & (1) & YES \\
\hline CEO duality & Yes & YES & YES & YES & YES & NO & N/A \\
\hline Audit committee & Yes & NO & NO & $\mathrm{NO}$ & $\mathrm{NO},(1)$ & NO & NO \\
\hline
\end{tabular}

